\title{
Using decoction of some vitamin $C$ enriched plants for the management of COVID-19 in Jos, Nigeria: A case report
}

\author{
Uchejeso M. Obeta1, ${ }^{1}$, Goodluck A. K. Ohanube², Maureen O. Ekpere-Ezeugwu33, Eno C. Mantu4,
} Nkereuwem S. Etukudoh5, Muhammad Akram, Imtiaz Mahmood Tahir7

${ }^{1}$ Department of Medical Laboratory Management, Federal School of Medical Laboratory Science, Jos, Nigeria ${ }^{2}$ Department of Biomedical Sciences, University of Applied Sciences, Bonn-Rhein-Sieg, Germany 3Department of Pharmaceutical Microbiology and Biotechnology, University of Nigeria, Nsukka, Nigeria 4 Department of Special Duties, Federal School of Medical Laboratory Science, Jos, Nigeria 5 Department of Haematology, Federal School of Medical Laboratory Science, Jos, Nigeria ${ }^{6}$ Department of Eastern Medicine, Government College University Faisalabad, Faisalabad, Pakistan ${ }^{7}$ College of Allied Health Professionals, Faculty of Medical Sciences, Government College University Faisalabad, Faisalabad, Pakistan

\begin{abstract}
The worldwide influence of coronavirus disease 2019 (COVID-19) pandemic compelled the global health organizations to prioritize the situation over all other related community health issues. The lack of specific treatment modalities against COVID-19 is a major concern nowadays. Here is a case of a 44year-old man of $176 \mathrm{~cm}$ height and $87 \mathrm{~kg}$ body weight, who took some powdered mixture equally composed of bitter kola, cinnamon, garlic, ginger, and turmeric sweetened with three teaspoons full of honey. All ingredients were dissolved in $100 \mathrm{ml}$ hot water and taken three times a day during isolation as a positive COVID-19 patient and reversed all associated signs and symptoms after 7 days as confirmed with rapid diagnostic techniques (RDTs). This case revealed that homogenized herbal tea in Jos Nigeria possesses a potential therapeutic that could be a treatment protocol against COVID-19.
\end{abstract}

Keywords: COVID-19, Herbal tea, Vitamin C enriched plants, Epigenetics, Homeostasis, Coronavirus

\section{Introduction}

Coronavirus disease 2019 (COVID-19) pandemic as declared by World Health Organization (WHO) has not gotten a confirmed cure worldwide [1], giving rise to many postulations with regards to treatment and management of the disease. While nonpharmaceutical ways of controlling the disease are duly encouraged to be practiced, many have tried various drugs for the treatment [2], and others have equally adopted many natural formulae to manage the situation depending on what is available in various domains $[3,4]$.

\footnotetext{
* Corresponding author:

Uchejeso M. Obeta, MSc.,MPA

Department of Medical Laboratory Management,

Federal School of Medical Laboratory Science, Jos, Nigeria

Tel/Fax: +2348039664892

Email: uchejesoobeta@gmail.com

http://orcid.org/oooo-0002-1382-6034
}

Received: February, 25, 2021

Accepted: April, 04, 2021
Such natural/herbal remedies included the use of natural plants [3,5], nutrients, and vegetables. The use of herbs can be in various prepared forms like powder, cold or boiled water extracts, or alcohol-based extract depending on the choice of the herbalist or the consumer. Such use of natural or herbal means to treat diseases has been practiced more in Africa in the past [3] and has been supported by WHO provided it follows a scientific and standardized approach [6].

The use of vitamin $C[7,8]$, vitamin $C$ enriched plants [9] in other forms such as water and alcoholbased extracts [10] have been encouraged for trials but 
this case was interested in the homogenized powder of such natural resources. Medical laboratory scientists, public health physicians, and academic researchers are seriously in search of prevention and cure of COVID-19 especially from natural products around Africa and across the world of which bitter kola, ginger, garlic, citrus, turmeric, and giloy are mostly mentioned not excluding vitamin $\mathrm{C}$ and vitamin $\mathrm{C}$ enriched plants and products [10-15].

This study aimed to educate healthcare professionals and caregivers in COVID-19 that the using decoction of some vitamin $\mathrm{C}$ enriched plants may be useful for the management of COVID-19 in Jos and possibly other parts of the world. This case study, therefore, was well monitored to ascertain if the dry products can as well be effective having tried liquid extracted ones within the pandemic with encouraging reports [7-10] as the dry products could easily be transported across the globe for trials and management of COVID-19 cases.

\section{Case presentation}

A certain business man 44-years-old in Jos developed COVID-19 like symptoms such as cough and catarrh, incessant sneezing, high temperature, loss of appetite, and general body pains. He is well built with $176 \mathrm{~cm}$ height and $87 \mathrm{~kg}$ body weight. He isolated himself at home and managed himself with home remedies as we recommended. The homemade remedy adopted was a powdered mixture of vitamin C enriched plants, namely; bitter kola, cinnamon, garlic, ginger, and turmeric. The equally measured homogenized powdered mixture of the five plants was prepared by dissolving three tablespoons full into a $100 \mathrm{ml}$ teacup with hot water and sweetened with honey. A cup of tea was taken in the mornings, afternoons, and evenings for 10 days. The patient was tested for COVID-19 after two days of commencing the herbal tea using the rapid diagnostic technique (RDT) called SD Biosensor Ag that was made in South Korea. After seven days, the patient was retested using the same COVID-19 rapid testing kit and the result was negative. Whereas all the signs and symptoms were completely ceased. The subject was impressed with such wonderful tea and gave his consent for his data to be published as of 20th September 2020. The subject could not disclose any past medical history but the authors present the details of the number of days it lasted, symptoms, tests performed, and recommended decoctions and medicines as presented in Table 1.

\section{Discussion}

COVID-19 pandemic ravages across the globe. There is an urgent need to discover a product that is effective and can be produced and packaged very well for effective logistics and delivery to every nook and cranny of the world. A very dry material or powder can be one of the ways to achieve this height.

In this case, the product in the powder is bitter kola, cinnamon, garlic, ginger, and turmeric with honey and hot water, and at various points have been analyzed to contain alkaloids, saponins, tannins, flavonoids, glycosides, sterols, phenols, carbohydrates, reducing sugars, proteins, oils, steroids fiber, enzymes, vitamin $\mathrm{C}$ with other vitamins, and vast micronutrients [16-19]. Just as honey contains water, fructose, glucose, sucrose, and other sugars, total protein, minerals, acids (such as gluconic acid), vitamins, enzymes, aromas, phenolic compounds, and some minor constituents [20-22]. These components including vitamin $\mathrm{C}$ are enriched with antioxidants, anti-inflammatory properties that seem to be good and effective remedies against the virus [10, 23-26] and in some cases against COVID-19 [27] just as vitamin $\mathrm{C}$ could be used for the treatment of other diseases [28].

There is no doubt that the herbal tea must have contributed to the fast recovery of the COVID-19 patient in this case. The effect and action may not be far from the epigenetics and homeostatic mechanisms advocated by our previous works [7-9]. Close observation in this case study showed that the patient's response to treatment was progressive. This result is in line with Girija and Sivan [29] as seen in Ayurvedic treatment of COVID-19. It sounds encouraging that Yang et al. [30] and Ren et al. [31] gave the perspectives of traditional Chinese medicine in relation to COVID-19 just as presented in this Nigerian case study.

This case can be said to be a Nigerian herbal tea for COVID-19 and calls for more research and better ways to do trials on the products used in the tea to enable, validations, registrations, and licensing by responsible government agencies. Confirmation of this case through further studies would encourage packaging and exportation to areas where COVID-19 is seriously affecting people to save lives across the world. Though 
Table 1. Case presentation and management

\begin{tabular}{|c|c|c|c|c|c|}
\hline $\mathbf{S} / \mathbf{N}$ & Day - Date & $\begin{array}{l}\text { Noticed signs and } \\
\text { symptoms }\end{array}$ & Test/ Result & Diet/Food & Treatment \\
\hline 1 & Day $1-10 / 09 / 20$ & $\begin{array}{l}\text { Dry cough, fever, } \\
\text { body pains, stomach } \\
\text { pains, loss of smell } \\
\text { and taste }\end{array}$ & $\begin{array}{c}\text { Temperature } \\
37^{\circ} \mathrm{C}\end{array}$ & $\begin{array}{l}\text { Pounded yam } \\
\text { and okro soup, } \\
\text { rice and stew, } \\
\text { cold water }\end{array}$ & $\begin{array}{c}\text { Paracetamol (2 Tablets, } \\
3 \text { times daily); Emzor } \\
\text { cough syrup ( } 20 \mathrm{ml} 3 \\
\text { times daily) }\end{array}$ \\
\hline 2 & Day $2-11 / 09 / 20$ & No difference & $\begin{array}{c}\text { Temperature } \\
38^{\circ} \mathrm{C}\end{array}$ & $\begin{array}{c}\text { Garri and } \\
\text { vegetable soup, } \\
\text { yam and beans, } \\
\text { warm water }\end{array}$ & $\begin{array}{c}\text { Same as above; } \\
\text { Vitamin C tablet } \\
\text { ( } 500 \mathrm{mg}, 3 \text { times daily); } \\
\text { decoction herbal tea ( } 3 \\
\text { times daily) with advice } \\
\text { to sleep very well and } \\
\text { drink warm water }\end{array}$ \\
\hline 3 & Day 3-12/09/20 & $\begin{array}{l}\text { Reduction in stomach } \\
\text { pains, others remained }\end{array}$ & $\begin{array}{c}\text { Temperature- } \\
38.5^{\circ} \mathrm{C} ; \\
\text { home RDT } \\
\text { test- } \\
\text { COVID-19 } \\
\text { positive }\end{array}$ & $\begin{array}{l}\text { Pounded yam } \\
\text { with vegetable } \\
\text { soup, locally } \\
\text { prepared fruit } \\
\text { juice, warm } \\
\text { water }\end{array}$ & $\begin{array}{c}\text { Vitamin } \mathrm{C} \text { as above; } \\
\text { decoction herbal tea as } \\
\text { above }\end{array}$ \\
\hline 4 & Day 4-13/09/20 & $\begin{array}{l}\text { Reduction in body } \\
\text { pains, stomach pains } \\
\text { and cough }\end{array}$ & $\begin{array}{c}\text { Temperature } \\
37^{\circ} \mathrm{C}\end{array}$ & Same as above & Same as above \\
\hline 5 & Day 5-14/09/20 & Same as above & $\begin{array}{c}\text { Temperature } \\
36.7^{\circ} \mathrm{C}\end{array}$ & Same as above & Same as above \\
\hline 6 & Day 6-15/09/20 & Stable and normal & Same as above & Same as above & Same as above \\
\hline 7 & Day 7-16/09/20 & $\begin{array}{c}\text { Same as above; } \\
\text { partial restoration of } \\
\text { sense of smell and } \\
\text { taste }\end{array}$ & Same as above & Same as above & Same as above \\
\hline 8 & Day 8-17/09/20 & $\begin{array}{l}\text { All signs and } \\
\text { symptoms gone }\end{array}$ & Same as above & Same as above & Same as above \\
\hline 9 & Day $9-18 / 09 / 20$ & & Same as above & Same as above & Same as above \\
\hline 10 & $\begin{array}{l}\text { Day 10- } \\
19 / 09 / 20\end{array}$ & - & $\begin{array}{c}\text { Temperature } \\
36^{\circ} \mathrm{C} \\
\text { home RDT } \\
\text { test- COVID- } \\
19 \text { negative }\end{array}$ & Same as above & Same as above \\
\hline 11 & $\begin{array}{l}\text { Day 11- } \\
20 / 09 / 20\end{array}$ & - & - & - & Same as above \\
\hline
\end{tabular}

the case might be limited by the fact that it is just one case at a time, further studies can tell more. Also, the dietary component, in this case, might have affected or contributed to the quick recovery of the patient. Another study could be carried out on the COVID-19 patients treated with the decoction herbal tea with diets of different climes.

COVID-19 has killed many especially in countries with good healthcare systems like the USA and UK. There is no confirmed conventional medical protocol and strategy for the cure. This case gives a hint towards herbal and natural remedies to the virus. Edible plants, vegetables, and nutrients could contribute immensely to the management of the COVID- 19 pandemic and should not be neglected no matter the area or country of origin. Such plants like bitter kola, cinnamon, garlic, ginger, and turmeric have consistently shown effectiveness against COVID-19 as liquid extracts and now as a powder in consideration of this case report. Notably, this case has further given credit to the Nigerian herbal remedies using vitamin $\mathrm{C}$ enriched plants including vegetables as they may have anti- 
COVID-19 properties that require consideration for curative medicine. It is suggestive to posit that homogenized herbal hot tea has potential therapeutics and could be a curative modality against COVID-19.

\section{Acknowledgments}

The authors appreciate the subject who gave consent to use the information for publication.

\section{Authors Contribution}

All Authors contributed equally and approved the final version of manuscript.

\section{Conflict of Interests}

The authors declare no competing interests.

\section{Ethical declarations}

This study was performed in accordance with the declaration of Helsinki and a signed informed consent was obtained from the patients for using the recommended remedy.

\section{Consent for publication}

Written informed consent was obtained from the patients for publication of this case report. A copy of the written consent is available for review by the Editor-in-Chief of this journal.

\section{Financial Support}

Self-funded.

\section{References}

1. Cucinotta D, Vanelli M. WHO Declares COVID-19 a Pandemic. Acta Biomed. 2020; 91(1):157-60.

2. Wang M, Cao R, Zhang L, Yang X, Liu J, Xu M, et al. Remdesivir and chloroquine effectively inhibit the recently emerged novel coronavirus (2019-nCoV) in vitro. Cell Res. 2020; 30(3):269-71.

3. Ezekwesili-Ofili Josephine Ozioma and Okaka Antoinette Nwamaka Chinwe (January 3oth 2019). Herbal Medicines in African Traditional Medicine, Herbal Medicine, Philip F. Builders, IntechOpen. Available from: https://www.intechopen.com/books/herbal-medicine/herbalmedicines-in-african-traditional-medicine.

4. Ikeagwulonu R, Etukudoh N, Ejinaka O, Ibanga I, Obeta M, UroChukwu H, et al. Profile of Some Trace Elements in Selected Traditional Medicines used for Various Aliments in Ebonyi State, Nigeria. Am J Biomed Sci \& Res. 2020; 9(3):239-44.

5. Akram M, Tahir IM, Shah SMA, Mahmood Z, AltafA, Ahmad K, et al. Antiviral potential of medicinal plants against HIV, HSV, influenza, hepatitis, and coxsackievirus: A systematic review. Phytother Res. 2018; 32(5):811-22.

6. World Health Organization and Food and Agriculture Organization of the United Nations. (2004). Vitamin and mineral requirements in human nutrition. Retrieved July 8, 2020. Available

from:

https://apps.who.int/iris/bitstream/handle/10665/42716/92415 46123.pdf.

7. Ohanube GA, Obeta UM, Ikeagwulonu CR. Case reports in the use of vitamin Cbased regimen in prophylaxis and management of COVID-19 among Nigerians. J Curr Biomed Rep. 2020; 1(2):7780.

8. Ohanube Goodluck A, Uchejeso O. COVID-19: Novel Opinion on Strategic Prophylaxis and Cure Using Vitamin C (Ascorbic Acid). Act Sci Nutr Health. 2020; 4(5):32-3.

9. Ohanube G, Obeta M, Ikeagwulonu R, Jwanse I. COVID-19: A Case Study of Using Vitamin C Enriched Plants and Ascorbic Acid as Cure. Am J Med Case Rep. 2020; 8(11):435-37.

10. Obeta M. Uchejeso, Ikeagwulonu R. Chinaza, Ohanube A.K. Goodluck and Jwanse I. Rinpan (November 9th 2020). Some Igbo Indigenous Plants with Anti-COVID-19 Properties [Online First], IntechOpen. Available from: https://www.intechopen.com/online-first/some-igboindigenous-plants-with-anti-covid-19-properties.

11. Tadepalli SP. Novel Remedial Approaches Against Virulent Corona Viruses. Int J Infect Dis Res. 2020; 1(1):1-15.

12. Mirzaie A, Halaji M, Dehkordi FS, Ranjbar R, Noorbazargan H. A narrative literature review on traditional medicine options for treatment of corona virus disease 2019 (COVID-19). Complement Ther Clin Pract. 2020; 40:101214.

13. Nandedkar M, Mahajan S, Pardeshi K, Oswal R, Shah M. Novel perception on the anti-viral effect of bioactive natural molecules against COVID-19. World J Pharm Res. 2020; 9(7):674-96.

14. Bharara A, Grossman C, Grinnan D, Syed A, Fisher B, DeWilde $\mathrm{C}$, et al. Intravenous Vitamin $\mathrm{C}$ Administered as Adjunctive Therapy for Recurrent Acute Respiratory Distress Syndrome. Case Rep Crit Care. 2016; 2016:8560871.

15. Ukaoma A, Ukaoma V, Okechukwu R, Iwuagwu $M$. Phytochemical screening and antibacterial properties of Garcinia kola. J Phytopharm. 2013; 2(3):34-8.

16. Ameh G, Eze S, Omeje F. Phytochemical screening and antimicrobial studies on the methanolic bulb extract of Allium sativum L. Afr J Biotechnol. 2013; 12(14).

17. Mbadiko CM, Inkoto CL, Gbolo BZ, Lengbiye EM, Kilembe JT, Matondo A, et al. A mini review on the phytochemistry, toxicology and antiviral activity of some medically interesting Zingiberaceae species. J Complement Altern Med Res. 2020; 9(4):44-56.

18. Jahan I, Onay A. Potentials of plant-based substance to inhabit and probable cure for the COVID-19. Turk J Biol. 2020; 44(3):22841.

19. Adarsh A, Chettiyar B, Kanthesh B, Raghu N. Phytochemical screening and antimicrobial activity of "Cinnamon zeylanicum". Int J Innovative Pharm Sci Res. 2020; 13:22-33.

20. Abeshu MA, Geleta B. Medicinal uses of honey. Biol Med. 2016; 8(2):1000279.

21. Alvarez-Suarez, J. M. (Ed.). (2017). Bee products-chemical and biological properties. Springer.

22. White JW. The Composition of Honey. Bee World. 1957; 38(3):57-66.

23. Figueroa-Méndez R, Rivas-Arancibia S. Vitamin C in Health and Disease: Its Role in the Metabolism of Cells and Redox State in the Brain. Front Physiol. 2015; 6:397. 


\section{Obeta et al.}

24. Carr AC, Maggini S. Vitamin C and Immune Function. Nutrients. 2017; 9(11).

25. Akbari A, Jelodar G, Nazifi S, Sajedianfard J. An Overview of the Characteristics and Function of Vitamin C in Various Tissues: Relying on its Antioxidant Function. Zahedan J Res Med Sci. 2016; 18(11):e4037.

26. Przybyło M, Langner M. On the physiological and cellular homeostasis of ascorbate. Cell Mol Biol Lett. 2020; 25(1):32.

27. Bukkuri A. A mathematical model showing the potential of vitamin c to boost the innate immune response. Open J Math Sci. 2019; 3(3):245-55.

28. Etukudoh NS, Uchejeso OM, Etim II. Bitter Kola (Garcinia kola) as Herbal Remedy for Diabetes. Curr Top Med Med Res. 2021; 12:61-8.

29. Girija PLT, Sivan N. Ayurvedic treatment of COVID-19/SARSCoV-2: A case report. J Ayurveda Integr Med. 2020. [In press]. doi: 10.1016/j.jaim.2020.06.001.

30. Yang Y, Islam MS, Wang J, Li Y, Chen X. Traditional Chinese Medicine in the Treatment of Patients Infected with 2019-New Coronavirus (SARS-CoV-2): A Review and Perspective. Int J Biol Sci. 2020; 16(10):1708-17.

31. Ren JL, Zhang AH, Wang XJ. Traditional Chinese medicine for COVID-19 treatment. Pharmacol Res. 2020; 155:104743. 